\title{
Intervensi Komunitas Spedagi dalam Pemberdayaan Ekonomi Masyarakat Berbasis Potensi Lokal di Pasar Papringan Temanggung
}

\author{
Dewi Ana Istianah \\ Institut Pesantren Mathaliul Falah Pati \\ sadewi.agustina@gmail.com \\ Nihayatuzzain \\ Universitas Islam Negeri Sunan Kalijaga Yogyakarta \\ Naskah diterima: 29 Mei 2020 | Naskah disetujui: 11 Juni 2020
}

\begin{abstract}
This paper discusses the role of a non-governmental organization and activist focusing on improving villages, the Spedagi community, in conducting empowerment in Ngadiprono Hamlet, Temanggung. The study aiming to also determine the impact of that empowerment was done through field research methods with a qualitative descriptive approach, while the data were collected through four techniques: interviews, observation, documentation and online data search. The analysis was carried out with the Miles and Huberman qualitative analysis model which included four stages: data collection, data reduction, data presentation and finally conclusion drawing and verification. The results of this study indicate that Spedagi has played a role as a community companion in Ngadiprono mainly in the economic empowering through the Papringan Market as an existing local potential, including: facilitative, educational, representative, and technical roles and skills. In addition, the socio-economic and even cultural life in Ngadiprono is also benefiting from the program.
\end{abstract}

Keywords: Community economic empowerment, local potential, traditional market

\begin{abstract}
Abstrak
Makalah ini membahas peran organisasi non-pemerintah dan aktivis yang berfokus pada pemberdayaan desa, yaitu komunitas Spedagi, dalam melakukan pemberdayaan di Dusun Ngadiprono, Temanggung. Bertujuan juga untuk menentukan dampak pemberdayaan yang dilakukan, penelitian ini menggunakan metode penelitian lapangan dengan pendekatan deskriptif kualitatif, di mana data dikumpulkan melalui empat teknik: wawancara, observasi, dokumentasi, dan pencarian data secara daring. Analisis dilakukan dengan model analisis kualitatif Miles dan Huberman yang meliputi empat tahap: pengumpulan data, reduksi data, penyajian data, dan akhirnya penarikan kesimpulan dan verifikasi. Hasil penelitian ini menunjukkan bahwa Spedagi telah berperan sebagai pendamping masyarakat di Ngadiprono terutama dalam pemberdayaan ekonomi melalui Pasar Papringan sebagai potensi lokal yang ada, termasuk peran dan keterampilan fasilitatif, edukatif, representatif, dan teknis. Selain itu, kehidupan sosial ekonomi dan bahkan budaya di Ngadiprono juga mendapat manfaat dari program ini.
\end{abstract}

Kata kunci: Pasar tradisional, pemberdayaan ekonomi masyarakat, potensi lokal

2716-0750 (C) 2020 The Author(s).

Published by LP2M INSURI Ponorogo. This is an open access article under the CC BY-SA 4.0 license. doi: 10.37680/amalee.v1i2.411 


\section{Pendahuluan}

Perbincangan mengenai pemberdayaan ekonomi masyarakat telah menjadi banyak perhatian oleh berbagai kalangan baik praktisi dan intelektual dari beragam bidang penelitian. Telah banyak pula literatur terdahulu yang mengupas dalam terkait tema ini, seperti dalam buku karya Jim Ife berjudul Community Development: Alternatif Pengembangan Masyarakat di Era Globalisasi yang berisi berbagai teori ekologi, sosial dan politik yang ditujukan membangun perspektif ekologis dan perspektif keadilan sosial/HAM secara teguh untuk menjadi landasan dalam praktik pengembangan masyarakat. Jim Ife menyatakan perlunya pengembangan masyarakat di tengah krisis yang melanda sebuah negara dengan tiga unsur penting yakni janji komunitas, modal sosial dan kebutuhan akan adanya orang asing dalam proses pengembangan masyarakat (Ife, 2008). Tiga unsur ini menjadi perhatian besar terutama jika pengembangan masyarakat ditujukan dalam wilayah pedesaan yang mayoritas penduduknya masih menjunjung tinggi gotong royong dan memiliki aset lokal meskipun sebagian desa belum sadar akan potensi tempat tinggalnya sehingga dibutuhkan pendamping, baik yang berasal dari luar daerah maupun dalam daerah tersebut sebagai penggerak desa untuk melakukan pengembangan masyarakat. Keadaan seperti ini tergambar pada masyarakat dusun Ngadiprono, Desa Ngadimulyo, Kecamatan Kedu, Kabupaten Temanggung, yang mana oleh sebuah komunitas bernama Spedagi mendapatkan perhatian untuk dikembangkan potensi lokalnya sehingga menjadi media pemberdayaan ekonomi mayarakat dusun Ngadiprono.

Spedagi, akronim dari "sepeda pagi", adalah sebuah komunitas yang awal mulanya hanya memiliki kegiatan rutin bersepeda yang dimulai oleh Singgih S. Kartono untuk kebutuhan menjaga kesehatan tubuh. Dengan berlatarbelakang profesi desainer, Singgih memiliki minat untuk mengembangkan desain sepeda bambu sejak tahun 2013. Seiring berjalannya waktu, sepeda bambu Spedagi bukan hanya menjadi sebuah produk berbasis sumber daya desa, namun juga menjadi picu awal lahirnya gerakan 'Revitalisasi Desa Spedagi', sebuah gerakan yang bertujuan membawa desa kembali ke harkat dasarnya sebagai komunitas yang lestari dan mandiri (Spedagi, 2013).

Spedagi melihat bahwa dewasa ini desa semakin ditinggalkan, senada dengan pandangan bahwa sebagian orang desa juga berpendapat bahwa mendapatkan pekerjaan di desa merupakan hal yang sulit sehingga banyak warganya yang berurbanisasi ke kota (Jamaludin, 2013). Kenyataannya, roda perekonomian di daerah pedesaan kebanyakan didominasi oleh aktifitas produksi. Aktifitas produksi yang relatif kurang beragam dan cenderung monoton pada sektor pertanian (dalam arti luas: perkebunan, perikanan, pertanian tanaman pangan, dan hortikultura, peternakan, kehutanan, dan produk turunannya). Jikapun ada aktifitas di luar sektor pertanian, jumlah dan ragamnya masih relatif sangat terbatas (Jamaludin, 2013). Demikian juga dengan masyarakat Desa Ngadimulyo, yang mayoritas penduduknya bermata pencaharian sebagai petani, namun tidak semua petani di daerah pedesaan memiliki lahan pertanian yang memadai. Banyak di antara mereka yang memiliki lahan pertanian kurang dari 0,5 hektar, yang disebut dengan istilah "petani gurem". Lebih ironis lagi, ada sebagian penduduk di daerah pedesaan tidak memiliki lahan pertanian garapan sendiri dan berstatus sebagai petani penyewa, penggarap, atau sebagai buruh tani. Petani penyewa adalah para petani yang tidak memiliki lahan pertanian garapan milik sendiri, tetapi menyewa lahan pertanian milik orang lain. Kondisi tersebut berpengaruh terhadap hidup dan penghidupan keluarga keluarga petani di daerah pedesaan. Perekonomian masyarakat di daerah pedesaan yang kurang menguntungkan mendorong penduduk desa untuk pindah ke darah perkotaan. 
Tidak sedikit pula kalangan muda desa yang menganggap bahwa desa tidak memiliki nilai ekonomi. Kehidupan desa yang identik dengan pertanian sebagai tiang penyangga atau sumber utama mata pencaharian masyarakatnya, kalah populer dengan sektor industri di kota-kota besar, yang akhirnya lambat laun menjadikan desa semakin terlupakan. Badan Pusat Statistik mencatat tingkat migrasi di Jawa Tengah di tahun 2015 mencapai hingga 6.551 .768 orang (BPS, 2015) Sedangkan menurut Data Dinas Kependudukan dan Catatan Sipil DKI Jakarta, pada tahun 2017 setelah lebaran, angka jumlah pendatang di Jakarta naik hingga 2,89\% atau 68.763 orang (Syadzily, 2017).

Terjadinya mobilitas masyarakat desa ke kota tersebut memberikan dampak negatif bagi desa itu sendiri. Desa menjadi semakin tertinggal dan tidak dipedulikan oleh warganya, padahal di sisi lain seharusnya desa menjadi sebuah komunitas lestari dan mandiri dengan berbagai macam kekayaan alam yang ada di dalamnya dan bisa menjadi modal bagi pembangunan masyarakat untuk menuju masyarakat yang mandiri, maju dan sejahtera.

Berangkat dari keresahan tersebut Komunitas Spedagi menggagas Gerakan Revitalisasi Desa, khususnya di Dusun Ngadiprono Desa Ngadimulyo, melalui Pasar Papringan yakni sebuah Pasar Desa berlokasi di kebun bambu yang notabenenya terletak di belakang rumah warga. Sekaligus sebagai bentuk gerbang ekonomi masyarakat desa dengan memanfaatkan segala potensi lokal yang ada sebagai bahan modal utama untuk dijual di Pasar Papringan tersebut. Dengan melakukan kegiatan kreatif di desa, diharapkan mampu menarik kembali para penduduk desa yang bermigrasi ke kota untuk kembali menengok daerahnya dan ikut serta di dalamnya. Dengan latar belakang demikian, maka menjadi penting untuk kemudian dilakukan penelitian atas Komunitas Spedagi terkait peran yang dilakukannya dalam memberdayakan ekonomi masyarakat Dusun Ngadiprono.

\section{Kerangka Teori dan Metode}

Sebagaimana dikutip oleh Edy Suhardono dalam bukunya, Bruce B. Biddle dan Edwin J. Thomas mengatakan bahwa istilah peran merupakan suatu penjelasan yang merujuk pada konotasi ilmu sosial, yang mengartikan peran sebagai suatu fungsi yang dibawakan seseorang ketika menduduki suatu posisi dalam struktur sosial. Menurutnya bahwa dalam kehidupan sosial nyata, membawakan peran berarti menduduki suatu posisi sosial dalam masyarakat, di mana seseorang (individu) maupun institusi sosial juga harus patuh pada skenario, yang berupa norma sosial, tuntutan sosial dan kaidah-kaidah. Hal tersebut menjadi seperangkat patokan yang membatasi apa perilaku yang mesti dilakukan oleh seseorang yang menduduki suatu posisi tertentu (Suhardono, 2016).

Senada dengan Biddle dan Thomas, Soerjono memaparkan bahwa peran merupakan suatu upaya atau langkah yang dilakukan oleh individu maupun organisasi dalam masyarakat terkait pemenuhan hak dan kewajiban sebagai konsekuensi dari kedudukan yang dimiliki (Soekanto, 1969). Dalam Kamus Sosiologi juga dijelaskan mengenai konsep peran, dikatakan bahwa peran (role) merupakan suatu perilaku atau tindakan yang ditentukan oleh apa yang diharapkan ketika seseorang (individu) maupun organisasi berada pada posisi sosial tertentu, bukan ditentukan oleh bagaimana karakteristik yang ada pada diri mereka (Abercrombie \& Hill, 2010). Sedangkan menurut Dahendrof dan Runciman, peranan sosial merupakan pola atau norma-norma perilaku yang diharapkan dari orang yang menduduki suatu posisi tertentu dalam struktur sosial (Burke, 2015). 
Dari beberapa pendapat di atas, dapat disimpulkan bahwa peran merupakan suatu upaya atau langkah yang dilakukan seseorang maupun suatu organisasi sesuai dengan posisi sosial yang sedang didudukinya. Dalam upaya pemberdayaan, pelaku perubahan memainkan peran sebagai pekerja sosial (community worker), dikatakan oleh Ife (2008) sebagaimana dikutip dalam bukunya Isbandi Rukminto (Adi, 2008) bahwa setidaknya ada empat peran dan keterampilan yang harus dimiliki oleh seorang community worker sebagai pemberdaya masyarakat. Keempat peran dan keterampilan tersebut adalah:

1. Peran dan keterampilan fasilitatif (fasilitative roles and skills) dimana terdapat tujuh peran khusus, yaitu animasi sosial (social animation), mediasi dan negosiasi (mediaton and negotiation), pemberi dukungan (support), membentuk konsensus (building consensus), fasilitasi kelompok (group fasilitation), pemanfaatan sumber daya dan keterampilan (utilization of skills and resources), serta mengorganisasi (organizing)

2. Peran dan keterampilan edukasi (education roles and skills). Meliputi empat peran yaitu, membangkitkan kesadaran masyarakat (consciousness raising), menyampaikan informasi (informing), mengonfrontasikan (confrontating), dan pelatihan (training)

3. Peran dan keterampilan perwakilan (representational roles and skills). Meliputi enam peran yakni, mencari sumber daya (obtaining resources), advokasi (advocating), memanfaatkan media (using the media), hubungan masyarakat (public relation), mengembangkan jaringan (networking), serta membagi pengetahuan dan pengalaman (sharing knowledge and exprience)

4. Peran dan keterampilan teknik (technical roles and skills). Sementara itu peran teknis mencakup, keterampilan pemberdaya masyarakat untuk melakukan penelitian (research), menggunakan komputer (using computers), melakukan presentasi tertulis maupun verbal (verbal and written presentation), serta kemampuan untuk mengontrol dan mengelola keuangan (management and financial control).

Di sini peneliti mencoba menelaah upaya-upaya pendampingan yang telah dilakukan oleh Spedagi terhadap masyarakat Dusun Ngadiprono dengan teori peran yang telah dipaparkan di atas dalam konteks pembentukan Pasar Papringan sebagai stimulus perekonomian di dusun tersebut. Penelitian ini bertujuan untuk mengetahui peran apa yang telah dijalankan oleh komunitas Spedagi dalam pemberdayaan ekonomi dusun Ngadiprono dan sejauh mana dampaknya bisa dirasakan oleh masyarakat dusun Ngadiprono.

Penelitian ini adalah penelitian lapangan dengan pendekatan deskriptif kualitatif dimana penulis langsung terjun ke lokasi penelitian untuk mengambil data primer lapangan, daerah atau lokasi tertentu (Bungin, 2008). Maksudnya adalah penelitian ini diarahkan untuk mengetahui peranan yang dilakukan oleh Komunitas Spedagi dalam melakukan pemberdayaan ekonomi masyarakat di Dusun Ngadiprono, Desa Ngadimulyo, Kecamatan Kedu, Kabupaten Temanggung, Provinsi Jawa Tengah. Sumber data dalam penelitian ini akan diperoleh dari berbagai sumber meliputi dua kategori yakni data primer dan data sekunder. Data Primer diperoleh dari wawancara baik secara lisan maupun tulisan kepada sumber utama yaitu Singgih S. Kartono selaku Ketua Spedagi, Fransisca Callista (Program Director \& Manager Pasar Papringan), Imam Abdul Rofiq (Ketua Komunitas Mata Air; Pengelola Pasar Papringan), Pratama Panji P. (relawan Pasar Papringan), dan Partini (relawan Pasar Papringan). Sedangkan sumber sekunder diperoleh dari data 
berupa dokumen tertulis maupun dokumentasi yang dimiliki oleh pihak bersangkutan baik kepala desa dan Komunitas Spedagi. Adapun pengumpulan data penelitian dilakukan melalui beberapa teknik, diantaranya teknik wawancara kepada narasumber, teknik observasi dengan mengamati keadaan di lokasi penelitian, dan melalui dokumentasi berupa data-data ataupun arsip gambar yang berkaitan dengan objek penelitian. Hasil yang didapat dari penelitian lapangan tersebut kemudian dideskripsikan dan dianalisis secara kualitatif untuk mencapai pemahaman yang menyeluruh (komperehensif).

\section{Hasil dan Pembahasan}

Berdasarkan elaborasi dari hasil wawancara serta observasi, peneliti menemukan bahwa Spedagi telah memainkan peranannya sebagai pendamping masyarakat dalam mengembangkan ekonomi Dusun Ngadiprono. Hal tersebut diwujudkan dengan adanya Pasar Papringan yang biasa disebut dengan Paspring oleh warga setempat.

\section{Pasar Papringan dan Peranan Komunitas Spedagi}

Pada awalnya, Pasar Papringan bertempat di Desa Kandangan, namun kemudian tutup karena ada alasan tertentu, dan dibuka kembali di Dusun Ngadiprono dengan ada inisiator lokal yakni Imam Abdul Rofiq dan telah bertahan hingga sekarang. Di dusun Ngadiprono ini sebelumnya sudah ada komunitas lokal yakni Komunitas Mata Air (KMA), hanya saja anggotanya satu persatu mulai hilang dan tersisa nama komunitasnya yang sudah dikenal warga. Di sinilah Spedagi membantu untuk membentuk ulang kelompok KMA tersebut menjadi kelompok baru yakni Kelompok Pasar Papringan yang sebagian anggotanya diisi oleh orang-orang yang dulunya aktif di komunitas KMA. Komunitas inilah yang menjadi sasaran dampingan oleh Spedagi. Hal ini didasari pula atas usul dari penggerak lokal dusun yang menginginkan untuk didampingi oleh Spedagi, dengan pertimbangan melihat potensi-potensi lokal yang ada di Dusun Ngadiprono. Sebelum terbentuknya kelompok Paspring, Spedagi bersama Imam berinisiasi melakukan survey dengan keliling Dusun Ngadiprono untuk memetakan masalah dan potensi yang ada. Maka bisa dikatakan pembentukan kelompoknya benar-benar dimulai dari nol, dengan bekal aset besar berupa masyarakatnya yang guyub rukun serta adanya inisiator lokal yang menjadi penggerak, hal ini menjadi modal sosial tersendiri bagi masyarakat (Callista, 2018).

Pasar Papringan menjadi sebuah contoh revitalisasi desa yang dimulai dari revitalisasi kebun bambu dan hal-hal terdekat yang ada di sekitarnya. Bagaimana mengubah kebun bambu yang semula menjadi tempat pembuangan sampah di lingkungan masyarakat desa menjadi ruang yang kembali disenangi masyarakatnya, memberikan keriangan dan kepercayaan diri bagi masyarakat yang hidup di dalam dan sekitarnya (Spedagi, 2017). Berbeda dengan pasar desa pada umumnya, Paspring terletak di kebun bambu dan menjual produk-produk lokal yang berkualitas sehingga nilai produk menjadi lebih tinggi dan masyarakat bisa mendapatkan manfaat ekonomi yang lebih besar. Kedatangan para pembeli dari luar kota bahkan luar negeri turut membangun rasa percaya diri masyarakat desa melalui produk lokal berkualitas yang dihasilkan (Spedagi, 2017).

Penjual di Paspring terbagi menjadi tiga kelompok, yang pertama kelompok pedagang kuliner, kedua kelompok pedagang kerajinan, dan ketiga kelompok pedagang hasil tani. Setiap kelompok 
mempunyai koordinatornya sendiri untuk memudahkan koordinasi yang berkaitan langsung dengan masing-masing job mereka (Joko, 2018).

Dalam upaya pemberdayaan di Dusun Ngadiprono, Spedagi juga memainkan peran sebagai pekerja sosial (community worker), dalam hal ini ada beberapa peran yang telah dimainkan oleh Spedagi, di antaranya :

1. Peran dan keterampilan fasilitatif (fasilitative roles and skills), yakni berupa: Memberi dukungan (support) kepada masyarakat dampingannya, fasilitasi kelompok (group fasilitation); mengawal masyarakat dalam hal koordinasi dan evaluasi setiap kegiatan serta menghubungkan masyarakat dengan pihak luar atau tim ahli yang sesuai dengan kebutuhan masyarakat, misal di bidang kuliner maka yang dibutuhkan adalah tim ahli bidang kuliner, untuk kemudian diadakan pelatihan dan diskusi mengenai hal-hal yang berhubungan dengan kuliner, mulai dari menentukan menu, harga, porsi, rasa, pengemasan, penjualan sampai visual, jenis-jenis dan pengembangan produknya, serta kualitas. Pemanfaatan sumber daya dan keterampilan (utilization of skills and resources) yakni dengan Bersama-sama merumuskan keperluan-keperluan masyarakat sesuai dengan kebutuhannya terkait dalam project Pasar Papringan, seperti pembagian job penjualan dan job kelompok perbidang. Dengan hasil akhir terbagi menjadi sembilan job bidang, pada setiap bidang terdapat koordinatornya masing-masing: 1) Tim Bidang Kuliner, 2) Tim Bidang Kerajinan Tangan, 3) Tim Bidang Hasil Tani, 4) Tim Bidang Keuangan, 5) Tim Bidang Pasar, 6) Tim Bidang Kebersihan, 7) Tim Bidang Parkir dan Keamanan serta 8) Tim Taman Bermain 9) Tim Bidang Kesenian, serta mengorganisasi (organizing), salah satunya diwujudkan dengan membantu untuk membentuk kelompok/komunitas lokal baru; Komunitas Pasar Papringan, sekaligus mendampingi dalam penataan manajemen baru untuk Pasar Papringan.

2. Peran dan keterampilan edukasi (education roles and skills), di antaranya yaitu, (1) Membangkitkan kesadaran masyarakat (consciousness raising), terutama dalam hal pengenalan potensi, peluang, kelemahan dan ancaman bagi pengembangan masyarakat. Kegiatannya dilakukan dalam bentuk pemetaan potensi dan pemetaan masalah secara bersama; (2) Menyampaikan informasi (informing) seperti mensosialisasikan kepada masyarakat terkait gambaran konsep Pasar Papringan yang akan menjadi garapan bersama di Dusun Ngadiprono; dan (3) Pelatihan (training) berupa pelatihan-pelatihan skill yang berkaitan dengan bidang penjual di Pasar Papringan yakni: kuliner, kerajinan dan hasil tani. Pelatihan dengan mendatangkan langsung tenaga ahli sesuai bidangnya, seperti pelatihan kerajinan tangan yang mendatangkankan narasumber desainer produk langsung dari Kashmir-India. Kemudian juga lokakarya kuliner yakni kolaborasi antara penjual kuliner dengan beberapa chef ahli langsung dari Jakarta untuk membuat menu kuliner baru.

3. Peran dan keterampilan perwakilan (representational roles and skills), meliputi beberapa peran yakni, (1) Spedagi mencari sumber daya (obtaining resources). Di awal-awal Spedagi dengan para pemuda termasuk inisiator lokal (Saudara Imam) bersama-sama melakukan observasi dengan keliling desa, musyawarah untuk mencari potensi-potensi desa baik dari sumber daya alamnya maupun sumber daya manusianya untuk mendukung terbentuknya Pasar Papringan, yang berjalan selama kurang lebih 6 bulan lamanya; (2) Memanfaatkan media (using the media) seperti media sosial dengan membuat akun official Instagram dan Facebook serta Website untuk mem-publish dan mempromosikan Pasar Papringan; (3) 
Hubungan masyarakat (public relation). Dalam hal ini beberapa anggota dari Spedagi memang tinggal dan menetap di Dusun Ngadiprono selama masa dampingan, sehingga memudahkan pihak Spedagi dalam penyebaran atau penyampaian informasi baik antar anggota Spedagi maupun kepada masyarakat; (4) Mengembangkan jaringan (networking) yakni menghubungkan masyarakat dengan pihak-pihak terkait yang mampu mendukung keberlangsungan pemberdayaan. Melobi berbagai pihak dalam hal pemasaran produk Pasar Papringan, seperti contohnya ikut dalam pameran di kota-kota besar, serta (5) Berbagi pengetahuan dan pengalaman (sharing knowledge and exprience) seperti berbagi edukasi kontekstual atau penyadaran kepada masyarakat, contohnya mengenai pemakaian bahan dasar atau bumbu masak yang sehat dan alami, yakni tidak mencapurkan bumbu masak dengan mono sodium glutamate (MSG). Kemudian memberikan edukasi bahwa sumber daya alam yang ada di sekitar sangat bisa dimanfaatkan sebagai bahan dasar untuk berjualan, sehingga tidak harus dengan membeli di luar dan mengeluarkan modal yang besar.

4. Peran dan keterampilan teknik (technical roles and skills), mencakup keterampilan pemberdaya masyarakat untuk melakukan penelitian (research), menggunakan komputer (using computers), melakukan presentasi tertulis maupun verbal (verbal and written presentation), serta kemampuan untuk mengontrol dan mengelola keuangan (management and financial control) (Callista, 2018).

Setelah mengetahui apa saja bentuk peran serta pendampingan dari Spedagi yang diberikan kepada masyarakat Dusun Ngadiprono, berdasarkan teori peran yang peneliti ambil dari Bruce B. Biddle dan Edwin J. Thomas (Suhardono, 1994), Spedagi sebagai pendamping sekaligus pekerja sosial telah membawakan peranannya sesuai dengan posisi yang sedang diduduki. Sebagai pendamping, Spedagi juga menjalankan perannya dengan tidak mendikte, mengatur dan memerintah masyarakat dalam proses pemberdayaan ekonomi yang dilakukan di Dusun Ngadiprono. Dengan kata lain, Spedagi justru menempatkan posisi masyarakat dampingannya sebagai subjek utama pemberdayaan, bukan sebagai objek.

\section{Manajemen Pemberdayaan Ekonomi melalui Pasar Papringan}

Pasar Papringan merupakan sebuah upaya untuk memberikan nilai lebih dari kebun bambu dengan memanfaatkannya menjadi pasar produk-produk lokal tanpa merusak kebun bambu itu sendiri. Jadwal operasional di Pasar Papringan juga berbeda dengan pasar-pasar desa pada umumnya, seperti yang dijelaskan oleh Panji pada saat pertama kali peneliti menginjakkan kaki di Pasar Papringan. Gelaran atau jadwal pasar untuk dibuka hanya setiap hari Minggu Wage dan Minggu Pon atau bisa dikatakan 2 kali tiap selapan (sistem kalender Jawa sejumlah 35 hari) mulai pukul 06.00 pagi sampai dengan pukul 12.00 siang (Panji, 2018). Semua pedagang dan pengelola Paspring adalah warga Dusun Ngadiprono sendiri, kecuali untuk bidang parkir dan sendra tari sebagian ada yang berasal dari dusun sebelah (Dusun Ngadidono), saat ini jumlah pedagang mencapai hingga 103 orang yang terdiri dari penjual kuliner sebanyak 82 orang, penjual kerajinan tangan sebanyak 18 orang, dan penjual hasil tani dan ternak sebanyak 3 orang. Semua elemen masyarakat diikutsertakan, baik muda-tua, lelaki-perempuan. Hal ini untuk memaksimalkan sumber daya manusia yang ada di dusun tersebut. Jumlah angka kerja terserap pada tahun 2018 mencapai 103 orang yang terlibat di Pasar Papringan (Rafiq, 2018). 
Produk-produk yang dijual di Paspring sebisa mungkin diharuskan berasal dari Dusun Ngadiprono sendiri baik untuk bahan dasar kuliner, kerajinan, hasil tani maupun ternak. Misalnya produk kerajinan tangan, maka semua bahan dasar bambu untuk membuat kerajinan diharuskan mengambil dari Dusun Ngadiprono, kecuali memang benar-benar tidak ada dan mengharuskan mencari di luar Dusun. Hal tersebut sebagai bentuk dari pemanfaatan sumber daya lokal yang ada, serta inisiatif meminimalisir modal yang dikeluarkan untuk berjualan (Afid, 2018). Di sisi lain tentu juga dilakukan penanaman ulang untuk bahan dasar yang digunakan agar tidak terjadi bentuk eksploitasi alam. Selain kerajinan, hasil bumi yang dijual juga merupakan hasil panen dari sawah para petani di Ngadiprono sendiri, begitu pun dengan hewan ternaknya (Hendro, 2018).

Kuliner atau makanan yang dijual di Pasar Papringan juga harus terbuat dari bahan alami, seperti singkong, kacang-kacangan dan lain sebagainya, selain itu dalam pembuatannya juga 'haram' hukumnya memakai bumbu MSG, begitu juga pengemasannya harus non-plastik yakni dengan menggunakan daun pisang, atau keranjang yang terbuat dari bambu. Menu kuliner yang ditawarkan di Pasar Papringan terbagi ke dalam beberapa jenis, yakni :

a. Makanan berat; seperti nasi gulai ayam, lontong mangut, sego jagung putih, sego gono, gudheg, soto lesah dan lain sebagainya.

b. Makanan ringan; seperti sate jamur, otak-otak jamur, ndas borok (terbuat dari ketela), gono jagung, klepon, sawut nanas, combro, srowol, tiwul iris, iwel-iwel, ketan cambah, citak, bal jindal, meniran, dan jajan ndeso lainnya.

c. Minuman dan jamu; ada kopi, wedhang pring, susu kedelai, dan berbagai jamu.

d. Camilan atau klethikan; ada akar kelapa pedas/manis, lantak pedas/ manis dan camilan lainnya.

e. Oleh-oleh, yakni makanan yang sudah dipacking dan bisa langsung dibawa pulang seperti telur asin, aneka macam sambal, aneka macam keripik, dan masih banyak lagi (Laelati, 2018).

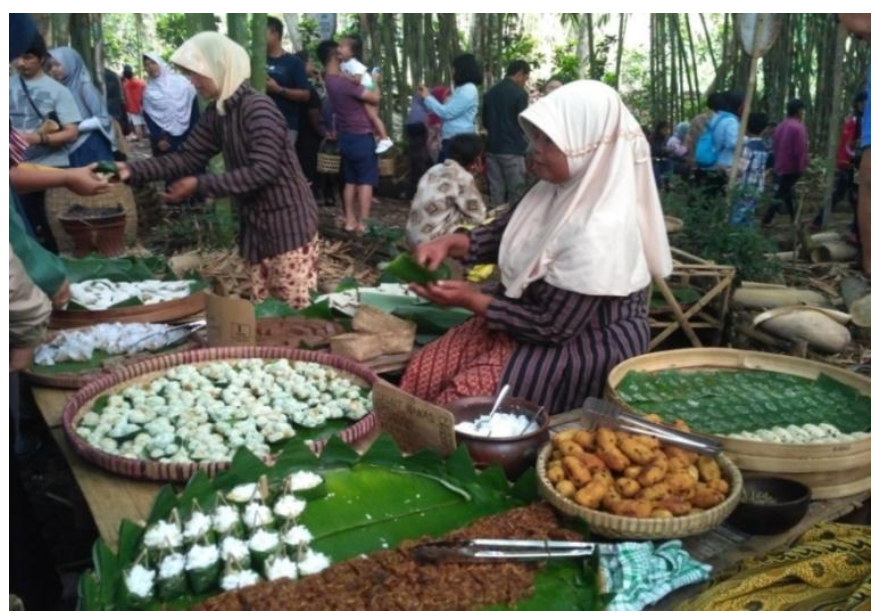

Gambar 1. Pedagang Kuliner Bagian Jajanan Ndeso di Pasar Papringan

Selain kuliner, kerajinan tangan juga terbagi ke dalam beberapa jenis karena setiap penjualnya boleh menyetorkan maksimal 4 kerajinan dan harus berbeda dengan kerajinan yang telah diajukan antar pedagang lain, yaitu: 
a. Mainan anak: Bedhil-bedhilan, sempritan, rally, gledekan fl, yoyo, gledhek ethek, truk tarik, truk dorong, kithiran godong, gasing, pesawat, ethek-ethek, sontokan, angkrek pantheng, dokar, dan sepur.

b. Gerabah: gelas, baki, tempat sendok, tempat buah, dan mangkok.

c. Perlengkapan rumah : tempat sabun, tabungan, pincuk, asbak, pot besar, pot kecil, keranjang besar, keranjang kecil, vas bunga, kipas, dan gantungan kunci (Afid, 2018).

Kemudian untuk hasil tani jenisnya dari sayur mayur, buah-buahan, kacang-kacangan, bumbu dapur serta ubi-ubian. Sedangkan untuk hasil ternak yang di jual Pasar Papringan ada kelinci, ayam, dan kambing (Hendro, 2018).

Sistem pengontrolan setiap bidang kelompok adalah para pedagang wajib mengumpulkan barang yang akan dijual kepada koordinatornya, sehari sebelum gelaran mulai, atau hari Sabtu siang. Hal ini bertujuan agar setiap warga atau pedagang di Paspring bisa ikut serta dalam persiapan sebelum gelaran, meliputi bersih-bersih lokasi, menata lokasi dagang, dan koordinasi kebutuhan setiap bidang kelompok. Koordinator kerajinan dipegang oleh Afid, untuk kuliner dikoordinasi oleh Ely Laelati, kemudian Hendro sebagai koordinator untuk bidang hasil tani dan ternak. Semua koordinator tersebut diharuskan untuk mengikuti rapat dengan koordinator inti setiap pra gelaran dan setelah gelaran (evaluasi), agar dapat mengontrol persiapan dan hasil setiap bidang (Rafiq, 2018).

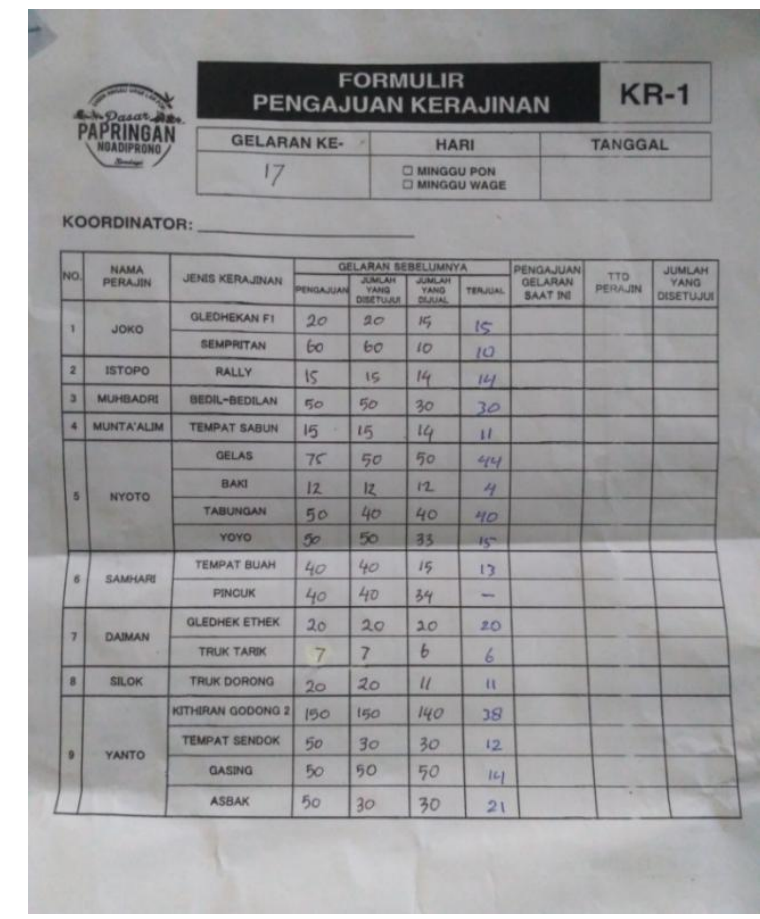

Gambar 2. Format Formulir Pengajuan Barang Dagang

Alat pembayaran yang digunakan di Pasar Papringan adalah mata kepingan uang dari bambu (pring) yang diproduksi sendiri oleh pihak pasar, di mana satu pring sama dengan Rp 2.000 (dua ribu rupiah). Sebelum memasuki area Paspring, pengunjung bisa menukarkan sejumlah uang rupiah dengan kepingan uang pring yang telah disediakan di beberapa titik meja penukaran. Di Pasar Papringan, alat pembayaran selain uang pring dianggap tidak sah (Ela, 2018). 


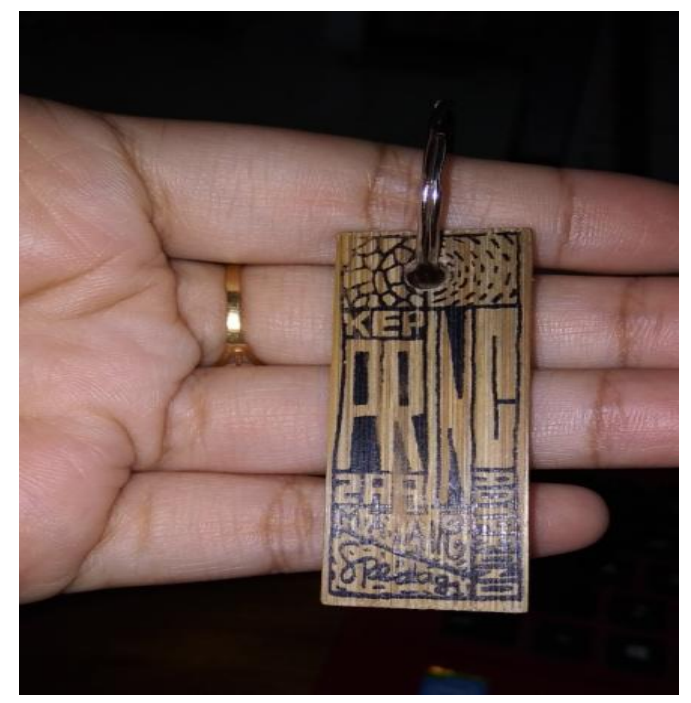

Gambar 3. Alat Pembayaran Sah di Pasar Papringan

\section{Pengaruh Pasar Papringan terhadap Perekonomian Masyarakat}

Untuk mengetahui pengaruh Pasar Papringan terhadap perekonomian masyarakat, peneliti membandingkan keadaan sosial Dusun Ngadiprono sebelum dan setelah adanya pasar tersebut. Secara signifikan, tampak bahwa Pasar Papringan telah membawa banyak dampak dalam kehidupan sosial di dusun tersebut, sebagaimana dalam perbandingan berikut:

\section{Keadaan Sosial Dusun Ngadiprono Pra Pasar Papringan}

Mayoritas profesi atau mata pencaharian warga Dusun Ngadiprono sebelum ada Pasar Papringan ialah petani. Kesehariannya dihabiskan untuk bertani di sawah, baik milik sendiri maupun milik orang lain sebagai buruh tani (Suparmo, 2018). Hal tersebut karena memang dusun ini terletak di kaki gunung Sumbing dan Sindoro, maka petani menjadi pilihan mata pencaharian umum bagi warganya. Di dusun ini terdapat banyak kebun bambu (Jawa: Papringan) namun hanya dipandang sebelah mata, seperti halnya di lain desa. Kebun bambu dipandang sebagai tempat yang gelap, kumuh dan terkesan mistis, bahkan di sana dijadikan sebagai tempat pembuangan sampah oleh warga lokalnya (Khotim, 2018). Dari pemaparan tersebut terlihat bahwa para warga Dusun Ngadiprono dulu, sebelum adanya Pasar Papringan, belum terbangun kesadaran dan mindset warga akan pentingnya nilai kebun bambu bagi kehidupan masyarakat desa.

Banyak penduduk Dusun Ngadiprono yang berurbanisasi ke kota untuk mencari pekerjaan yang lebih menjanjikan ketimbang hanya mengandalkan penghasilan dari seorang petani. Mereka memiliki pandangan bahwa apa yang ada di desa tidaklah cukup untuk memenuhi kebutuhan yang kian bertambah di zaman yang serba modern ini. Selain merantau ke kota untuk mencari pekerjaan, beberapa juga ada yang merantau untuk mengenyam pendidikan di kota-kota besar hingga bertahun-tahun dan kemudian memilih untuk hidup di kota daripada di kampung sendiri yang dalam pandangan mereka masih tertinggal dan tidak menarik sama sekali. 


\section{Keadaan Sosial Pasca Pasar Papringan}

Pasar Papringan yang dirilis sejak awal 2016 dan bertahan hingga sekarang, telah membawa banyak manfaat dan dampak positif bagi warga dan kehidupan sosial-ekonominya. Tentu di balik itu usaha yang dikerahkan oleh masyarakat dan pendampingnya memakan banyak tenaga dan waktu. Meski begitu, jerih payah tersebut terbayar dengan hasilnya. Seiring berjalannya Pasar Papringan di Dusun Ngadiprono, semakin tumbuh dan terbentuk pula kesadaran masyarakatnya terhadap perbaikan desa dan taraf hidupnya. Terlatih untuk peka terhadap kondisi sekitar membuat masyarakatnya menjadi lebih menghargai segala bentuk potensi sumber daya yang ada di daerahnya, masyarakat menjadi lebih sadar betapa pentingnya kebun bambu bagi kehidupan sehari-sehari di desa (Callista, 2018).

Keterlibatan masyarakat dalam Pasar Papringan menjadikan antar warga mau tak mau harus sering bertemu dan berkumpul. Dari hal tersebut menjadikan ikatan antar warga semakin erat, saling rukun dan guyub sesama warganya. Adanya Pasar Papringan pun menjadikan ketertarikan tersendiri bagi warganya untuk kembali dan ikut berpartisipasi di dalam desa (Callista, 2018). Di sisi lain, yang paling terlihat adalah Pasar Papringan menjadi pintu masuknya perkembangan ekonomi di Dusun Ngadiprono. Seperti keterangan yang dipaparkan oleh Joko, salah satu pedagang kerajinan di Paspring:

"Meskipun kadang warga nggeh nganggep e kegiatan berdagang di Pasar Papringan niku dados pekerjaan sampingan, tapi pemasukan sing saking Paspring niku cukup menjanjikan lho mbak, njuk dadose nggeh saget kagem tambah-tambah kalehan menutupi kebutuhan mbak memang, rata-rata kulo sekali gelaran niku saget angsal 500 pring mbak, dengan tanpa mengeluarkan modal banyak. Kalo penghasilan di luar Pasar Papringan nggak sampe segitu mbak."(Joko, 2018).

Dari keterangan di atas terlihat bahwa dengan adanya Pasar Papringan turut menjadi lokomotif penggerak perekonomian di Dusun Ngadiprono, yang menurut pengakuan Joko, omzet yang diperoleh tiap gelaran mencapai 500 pring atau senilai Rp. 1.000.000. Secara keseluruhan, omzet yang didapat oleh Pasar Papringan mencapai hingga Rp 120.000.000 (seratus dua puluh juta rupiah) untuk sekali gelarannya (Ela, 2018) . Dan untuk menjalin kolektivitas komunitas, dari hasil penjualan tersebut, setiap kali gelaran para pedagang diwajibkan menyisihkan 10\% hasil pendapatannya untuk ditabungkan pada Koordinator Bidang Keuangan. Tabungan tersebut dipergunakan untuk menunjang kebutuhan para warga, seperti halnya untuk biaya pendidikan dan kesehatan, sehingga para warga dapat mencukupi kebutuhan untuk membiayai pendidikan anak-anaknya dan membiayai kebutuhan berobat jika diperlukan.

Selain manfaat ekonomi yang didapat dari berjualan di Pasar Papringan, para warga juga menjadi lebih terlatih keterampilan dan kreativitasnya untuk mengolah sumber daya potensi lokal yang ada di sekitarnya dijadikan sebagai produk untuk dijual. Contoh saja, dari 18 penjual kerajinan, setiap orangnya menawarkan berbeda-beda jenis kerajinan dengan batas maksimal pembuatan empat jenis bentuk kerajinan per orangnya, sehingga masyarakat menjadi lebih berdaya terhadap keadaan hidupnya. Pendidikan kontekstual yang diberikan oleh pendamping, juga berdampak pada aspek kesehatan masyarakatnya, dimulai dari peraturan berjualan kuliner dengan konsep makanan non-MSG, menjadikan beberapa warga lebih peduli dengan komposisi setiap makanan yang akan dimakan, baik yang dimasak sendiri 
maupun membeli dari luar. Para warga terutama para ibu benar-benar mempraktekkannya dalam kehidupan sehari-sehari dengan kesadaran penuh untuk memperhatikan kualitas kesehatan keluarganya.

Pasar Papringan juga memberi dampak secara tidak langsung terhadap budaya dan spiritualitas masyarakat dusun Ngadiprono. Tampak dari para penjual misalnya, dalam melayani pembeli harus berlatih untuk sabar, jujur, dan giat. Selain itu nilai guyub rukun yang sudah tertanam, saling bekerja sama, menjaga kebersihan dan tidak merusak sumber daya yang ada di sekitarnya adalah contoh dampak dalam bentuk nilai secara implisit yang didapat oleh masyarakat.

\section{Kesimpulan}

Banyak masyarakat utamanya yang tinggal di desa tidak menyadari akan besarnya potensi yang ada di tempat tinggal mereka. Sehingga tidak jarang dari mereka berbondong-bondong melakukan urbanisasi mengadu nasib di perkotaan berharap mendapatkan kehidupan yang layak. Sementara desa akhirnya menjadi wilayah yang tidak terurus dan tertinggalkan karena kehilangan para pemudanya. Inilah kemudian yang memunculkan sikap perhatian dan peduli para aktivis sehingga banyak hadir pendamping desa baik dari pemerintah maupun swasta seperti komunitas Spedagi ini. Spedagi berusaha membangun ekonomi desa dengan memanfaatkan potensi yang ada di Dusun Ngadiprono yaitu kebun bambu yang dulunya hanyalah tempat pembuangan sampah disulap menjadi pasar Papringan. Pemberdayaan ekonomi di pedesaan perlu digalakkan untuk meningkatkan sumber daya manusia dan sumber daya alam sehingga terciptalah masyarakat desa yang lebih mandiri dan tidak melulu menggantungkan nasib di perkotaan. Sudah saatnya pula desa dikenal oleh daerah lain dengan kearifan lokalnya sehingga pada akhirnya dapat mendatangkan wisatawan dari luar daerah atau bahkan wisatawan asing sehingga diharapkan pendapatan desa serta masyarakat sekitarnya bisa naik dan sejahtera.

\section{Pernyataan}

Ucapan terima kasih peneliti utarakan kepada komunitas Spedagi dan pengelola Pasar Papringan Dusun Ngadiprono, Desa Ngadimulyo, Kecamatan Kedu, Kabupaten Temanggung yang telah bersedia membantu penulis dalam melakukan penelitian. Tak lupa seluruh pihak yang telah mendukung dan berkontribusi dalam mewujudkan penelitian ini, rasa terima kasih turut peneliti sampaikan.

\section{Daftar Pustaka}

Adi, I. R. (2008). Intervensi Komunitas Pengembangan Masyarakat Sebagai Upaya Pemberdayaan Masyarakat. Jakarta: Raja grafindo Persada.

Adon Nasrullah Jamaludin. (2013). Sosiologi Perdesaan. Bandung: In Journal of Chemical Information and Modeling (Vol. 53, Issue 9). https://doi.org/10.1017/CBO9781107415324.004

Afid. (2018, April 29). Manajemen Pasar Papringan. (D. A. Istianah, Pewawancara) 
BPS. (2015). Migrasi Seumur Hidup menurut Provinsi, 1971-2015. https://www.bps.go.id/dynamictable/2015/09/07/855/migrasi-seumur-hidup-menurutprovinsi-1971-2015.html

Bungin, M. B. (2008). Penelitian kualitatif: Komunikasi, Ekonomi, Kebijakan Publik, dan Ilmu Sosial Lainnya. Jakarta: Kencana Prenada Media Group.

Burke, P. (2015). Sejarah dan Teori Sosial (edisi ke d). Jakarta: Pustaka Obor Indonesia.

Callista, F. (2018, April 29). Peran Komunitas Spedagi di Pasar Papringan. (D. A.Istianah, Pewawancara)

Ela. (2018, Mei 12). Pengelolaan Keuangan Pasar Papringan. (Nihayatuzzain, Pewawancara)

Hendro. (2018, Mei 12). Manajemen Hail Tani di Pasar Papringan. (D. A. Istianah, Pewawancara)

Ife, J. (2008). Community development : alternatif pengembangan masyarakat di era globalisasi (S. Z. Qudsy, Ed.). Yogyakarta: Pustaka Pelajar.

Joko. (2018, April 27). Manajemen Pasar Papringan. (Nihayatuzzain, Pewawancara)

Khotim. (2018, April 28). Keadaan Sosial Dusun Ngadiprono. (D. A. Istianah, Pewawancara)

Laelati, E. (2018, April 28). Pengelolaan Bidang Kuliner di Pasar Papringan. (D. A. Istianah, Pewawancara)

Nicholas Abercrombie, Stephen Hill, B. S. T. (2010). Yogyakarta: Kamus Sosiologi. Pustaka Pelajar.

Panji P. (2018, April 22). Pasar Papringan dan Dampaknya. (D. A. Istianah, Pewawancara)

Rafiq I. A. (2018, April 22). Manajemen Pasar Papringan. (Nihayatuzzain, Pewawancara)

Soekanto, S. (1969). Sosiologi Suatu Pengantar. Jakarta: Yayasan Penerbit Universitas Indonesia.

Spedagi. (2013). History of Spedagi. https://www.spedagi.com/history

Spedagi. (2017). Gerakan Kreatif untuk Revitalisasi Desa. Temanggung: Komunitas Spedagi.

Suhardono, E. (2016). Teori Peran: Konsep, Derivasi dan Implikasinya. Jakarta: PT Gramedia Pustaka Utama.

Suparmo. (2018, April 27). Keadaan Sosial-ekonomi Dusun Ngadiprono. (D. A. Istianah, Pewawancara)

Syadzily, A. H. (2017). Urbanisasi dan Kesenjangan Kota-Desa. Sindonews.com. https://nasional.sindonews.com/berita/1222235/18/urbanisasi-dan-kesenjangan-kota-desa 